\title{
EFFECT OF MULTI-PASS FRICTION STIR PROCESSING ON THE MICROSTRUCTURE AND MECHANICAL PROPERTIES OF DUAL PHASE STEEL
}

\author{
T. KÜÇÜKÖMEROĞLU' ${ }^{1}$, S. M. AKTARER ${ }^{2}$, G. İPEKOĞLU ${ }^{3}$, G. ÇAM ${ }^{3}$ \\ ${ }^{1}$ Department of Mechanical Engineering, Karadeniz Technical University, Trabzon, Turkey. E-mail: tkomer@ktu.edu.tr \\ ${ }^{2}$ Department of Automotive Technology, Recep Tayyip Erdogan University, Rize, Turkey. E-mail: semih.aktarer@erdogan.edu.tr \\ ${ }^{3}$ Department of Mechanical Engineering, Iskenderun Technical University, 31200 İskenderun-Hatay, Turkey. \\ E-mail: guven.ipekoglu@iste.edu.tr; gurel.cam@iste.edu.tr
}

\begin{abstract}
Dual phase (DP) steels have been widely used in the automotive industry due to the excellent engineering properties such as high strength and good formability. However, attempts have recently been ongoing to improve their mechanical and formability properties in order to achieve further weight savings. Mechanical and microstructural properties of DP steel can be improved by severe plastic deformation (SPD) techniques without changing their chemical compositions. Among SPD methods, friction stir processing (FSP) is a new method used to enhance the properties of plate and/or sheet types of metals. Therefore, the effect of multi-pass FSP (M-FSP) on the microstructure and mechanical performance of a DP steel (i.e., DP600) was investigated in the current study. M-FSP was applied to dual phase steel at the $4 \mathrm{~mm}$ steps. FSP resulted in a refined microstructure which brought about a considerable increase in both hardness and strength values. After FSP, islands of martensite as the secondary phase in the microstructure have been broken and disturbed by the rotational pin. The processed region consists of ferrite, bainite and martensite. The hardness value increased from 210 HV0.2 to about 360 HV0.2 after M-FSP. 36 Ref., 1 Tabl., 4 Fig.
\end{abstract}

\section{Keywords: friction stir processing, dual-phase steel, fine grained microstructure, mechanical properties}

\section{Introduction}

Dual Phase (DP) steels are widely used in the automotive industry due to their excellent mechanical properties such as high strength and good formability [1-3]. However, numerous studies have recently been conducted to improve the strength and ductility of these steels which in turn further reduce the weight and ensure safety [4-6]. The mechanical properties of DP steels can be improved by severe plastic deformation (SPD) techniques without changing their chemical compositions $[7,8]$. Friction stir processing (FSP) is a novel SPD method which can be used for the improvement of properties. It can even be said that friction stir process is the most ideal method among the SPD methods when considering the processing of large scale plate or sheet type materials [9].

FSP is based on the basic principles of friction stir welding (FSW) [10], which is originally developed for joining difficult-to-weld Al-alloys [11-14]. FSP is a method of improvement of the properties of a material by way of severe, localized plastic deformation which is produced by immersing a nonconsumable tool into the work piece, and rotating and traveling the tool in a stirring motion [15]. Many review papers on this process have been published until now, and thus detailed information on its principles can be obtained in Refs. [16-19]. As the FSP deforms a limited region, the multi-pass FSP, which is applied sequentially, leads to deformation of larger regions and allows material properties to be improved in large-scale dimensions. Up to now, multi-pass FSP has been applied to mostly aluminum alloys [20-25] and few magnesium alloys [26-28] and pure titanium [29]. Generally, it was reported that multi-pass FSP improves mechanical properties of cast Al alloys containing $\mathrm{Si}$ and achieves significant microstructural refinement [25,30-32]. Aktarer et al. [33] reported that two-pass FSP of A112Si alloy leads to fragmentation of needle-shaped silicon plates from $27 \pm 23 \mu \mathrm{m}$ to about $2.6 \pm 2.4 \mu \mathrm{m}$, thus both strength and ductility are remarkably increased, i.e., about 1,3 and 7 times than that of base metal, respectively. Similarly, Lua et al. showed that multi-pass FSP significantly improved both strength and ductility of cast magnesium alloys such as AZ61 due to grain refinement and the elimination of cast defects [26]. Also, corrosion behavior of multi-pass friction stir processed (FSP) pure titanium was investigated by Fattah-Alhosseini et al. [29]. They found that grain refinement in the multi-pass FSPed sample led to a reduction in both corrosion and passive current densities.

Although there are many reports on multi-pass FSP (M-FSP) of non-ferrous alloys and single-pass FSP of steels [33,34], only limited amount of studies have been undertaken systematically on the (M-FSP) of steels. Furthermore, more studies are needed for 
getting further improvement in mechanical properties of multi-pass friction stir process of dual phase steel. Therefore, the main purpose of this study is to determine the effect of multi-pass FSP on the microstructural evolution, microhardness and tensile properties of a dual phase steel (i.e., DP600).

\section{Experimental Procedure}

Hot rolled DP600 steel with a chemical composition of $0.040 \% \mathrm{C}, 1.436 \% \mathrm{Mn}, 0.239 \% \mathrm{Si}$, $0.047 \% \mathrm{Al}, 0.035 \% \mathrm{Cu}, 0.690 \% \mathrm{Cr}, 0.039 \% \mathrm{Ni}$, $0.011 \%$ Mo and balance Fe was used in this study. Samples with the dimensions of $200 \mathrm{~mm} \times 50 \mathrm{~mm}$ $\times 1.5 \mathrm{~mm}$ were cut from the steel plate for multipass friction stir processing (M-FSP). M-FSP was performed with a processing tool having a flat shoulder with the diameter of $14 \mathrm{~mm}$ and a cylindrical pin with the diameter and length of $5 \mathrm{~mm}$ and $1.3 \mathrm{~mm}$, respectively. In FSP trials, a tool rotational rate of $1600 \mathrm{rpm}$ and a traverse speed of $170 \mathrm{~mm} / \mathrm{min}$ were used. The shoulder tilt angle was set at $2^{\circ}$, and the tool downforce was kept constant at $6 \mathrm{kN}$ during process. The subsequent M-FSP was shifted toward the advancing side with stepping of $4 \mathrm{~mm}$, thus a total of 3 overlapping passes were carried out on the DP600 steel sheet. Schematic illustration of M-FSP process is shown in Fig. 1.

Optical microscopy (OM) and scanning electron microscopy (SEM) were used to observe the microstructure of the samples before and after M-FSP. The metallography specimens were extracted perpendicular to the processing direction (Fig. 1), polished with standard techniques and then etched in $\% 2 \mathrm{Nital}\left(3 \mathrm{ml} . \mathrm{HNO}_{3}+97 \mathrm{ml} . \mathrm{C}_{2} \mathrm{H}_{6} \mathrm{O}\right)$ for $20 \mathrm{~s}$. Mechanical properties of the base and M-FSPed samples were determined using tensile test and hardness measurements. Dog-bone shaped tensile test specimens with the gauge dimensions of $1.4 \mathrm{~mm} \times 3 \mathrm{~mm} \times 8 \mathrm{~mm}$ were extracted from the base material and M-FSPed plates by electro discharging machining (EDM) technique. These specimens were cut parallel to the process direction at three different positions inside the FSPed region as shown in Fig. 1. The positions of the tensile test specimens are representative of the center of each pass FSP region shifted to $4 \mathrm{~mm}$ steps. The tests were performed using an electro-mechanical load frame with a video type extensometer at a strain rate of $5 \cdot 10^{-4} \mathrm{~s}^{-1}$. Vickers micro-hardness tests were carried out using a load of $200 \mathrm{~g}$ and a dwell time of $10 \mathrm{~s}$. Vickers microhardness measurements were conducted throughout the cross section of the processed specimen with an interval of $250 \mu \mathrm{m}$ as illustrated in Fig. 1.

\section{Results and Discussion}

\subsection{Microstructure}

Optical micrographs showing the microstructures of DP600 steel base plates are given in Fig. 2. The initial microstructure of DP600 steel sheet is consisted of elongated ferrite grains in rolling direction and dispersed martensite throughout ferrite grain boundaries. Average ferrite grain size was $6 \mu \mathrm{m}$ and the volume fraction of martensite was determined to be approximately $24 \%$. Martensite islands appear dark in optical micrograph (Fig. 2(a)) and they seem bright in SEM image (Fig. 2(b)).

An optical macrograph of M-FSPed region is given Fig. 3(a), and the traces of the side-byside pass are clearly visible. Final pass processed

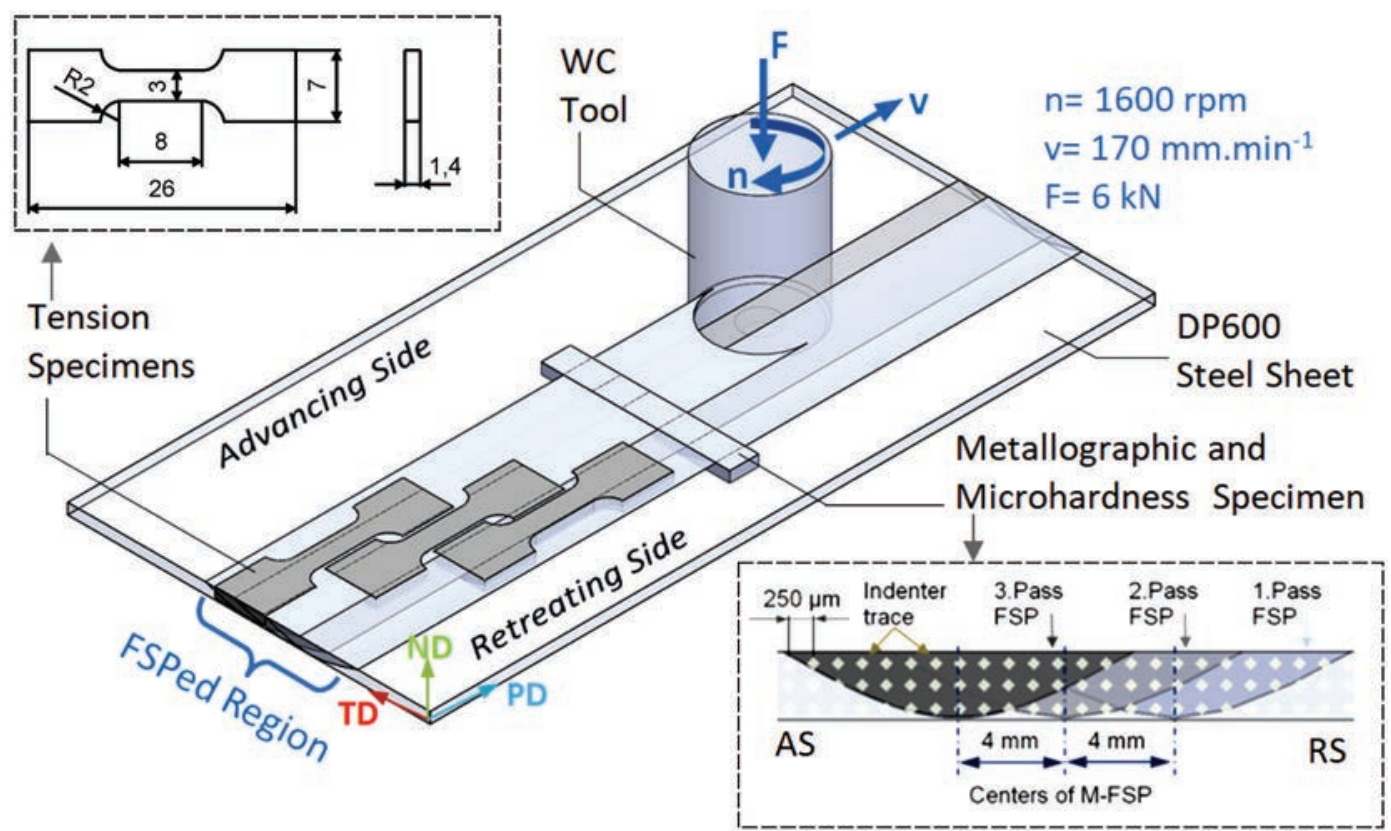

Fig. 1. Schematic illustration of M-FSP technique which shows the specimens' geometries extracted from the FSPed sheet and the position from which they were extracted 

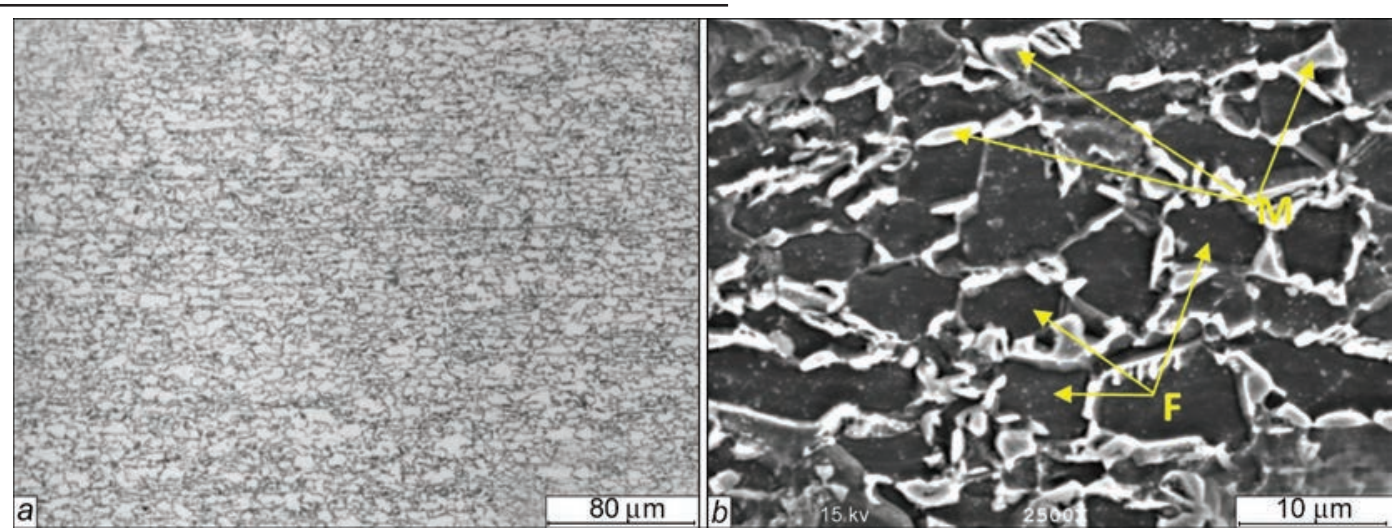

Fig. 2. Micrographs showing the microstructure of DP600 steel base plate: (a) optical micrograph and (b) SEM image

microstructure is shown in Fig. 3(b), which is almost entirely lath martensite. This zone is seen as a darker region in macrograph. The region exhibits a similar characteristic to single-pass FSP microstructures. Since the process does not continue then there is no heat or deformation to affect this region. However, it is a fact that the heat and deformation of the 2 nd pass process affects the 3 rd processed zone and it can be separated into single pass FSP. The lath martensite formed in the microstructure shows that this region is completely austenite during the process. Therefore, it can be said that the process temperature is above the A3 temperature line. Miles et al. [35] is reported that lath martensite is observed in $\mathrm{SZ}$ of friction stir welded DP590 steel. The microstructure in the $\mathrm{SZ}$ of the second pass process is shown Fig. 3(c), which also corresponds to the heat affected zone of the third process. Therefore, while microstructure of this region is fully lath martensite after the 2nd pass process, it is transformed to acicular products by heat generated by the $3 \mathrm{rd}$ pass process. This microstructure consists of lath martensite and dispersed acicular and globular cementite through the ferrite matrix as seen Fig. 3(c). The SZ of 1st pass process is actually the heat affected zone of 2nd pass process and its microstructure is given Fig. 3(d). A predominantly bainitic structure is observed in this region, and the formation of various types of acicular

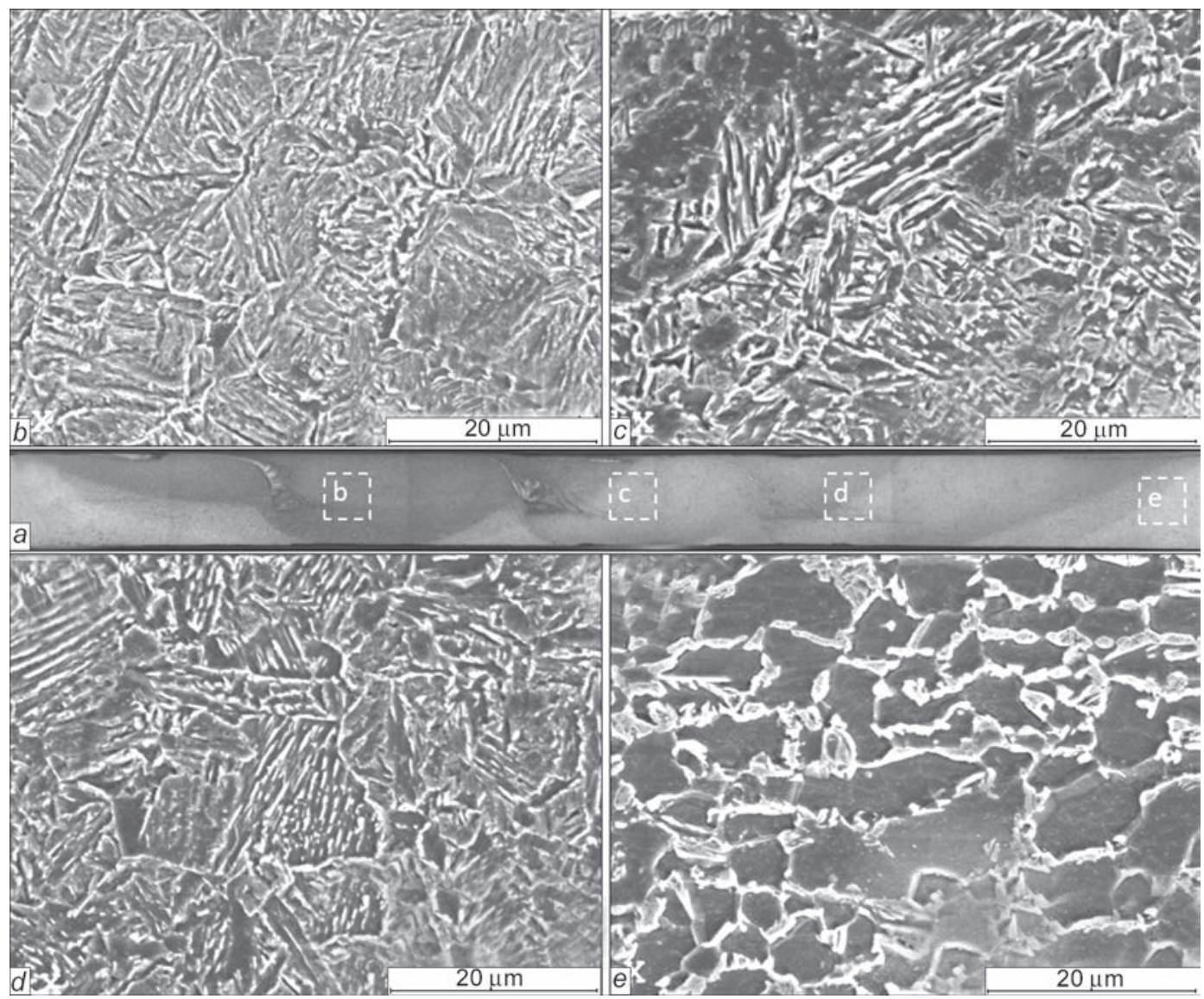

Fig. 3. Optical macrograph of the cross-section of M-FSPed specimen (a), the SZ center of 3rd pass (b), the SZ center of 2nd pass (c), the $\mathrm{SZ}$ center of 1 st pass (d), heat affected zone (HAZ) of 1st pass at the retracting side (e) 


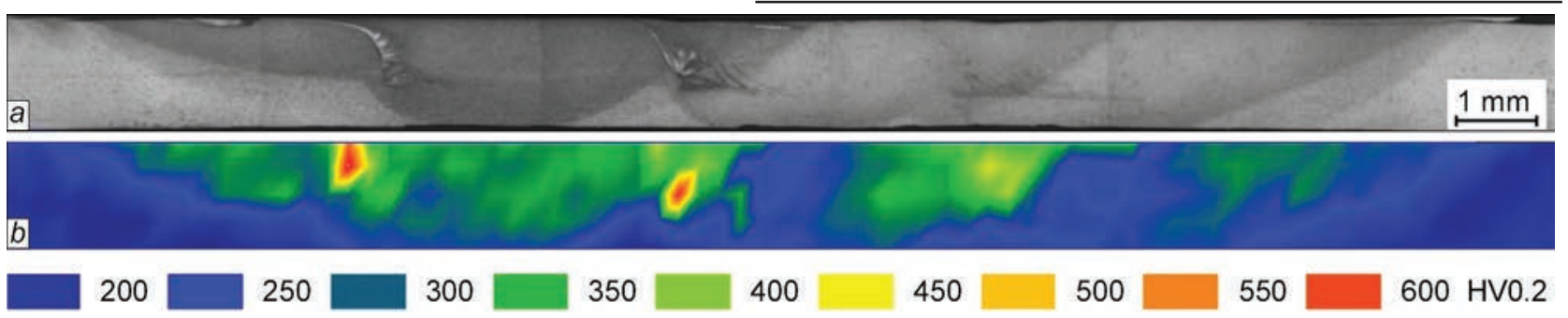

Fig. 4. Optical microstructure of cross section of the M-FSPed sample extracted perpendicular to the process direction (a); a contour map showing the hardness distribution across the M-FSPed region (b)

products depends on the peak temperature, the cooling rate and the rate of deformation during the process. Kang et al. [36] reported that microstructures of bainite and martensite may form at different cooling rates in FSPed low-alloy high-strength steel. Their results clearly showed that the microstructure comprises of completely bainite at a cooling rate of $30{ }^{\circ} \mathrm{C} / \mathrm{s}$ and dominantly martensite at a cooling rate of $70^{\circ} \mathrm{C} / \mathrm{s}$.

The microstructure of HAZ of 1 st pass process at the retracting side is tempered martensite which consists of very small and uniformly dispersed cementite [37]. Fig. 3(c) shows tempered martensite partially decomposing into cementite and ferrite from martensite islands in the HAZ.

\subsection{Microhardness and Tensile Prosperities}

The microhardness profile showing the hardness distribution across the M-FSPed region is given in Fig. 4. The DP 600 steel base plate has a hardness of $210 \mathrm{HV}$. The highest hardness in the processed zone is approximately $550 \mathrm{HV}$, which is measured around the pin. The average hardness value of the stir zone corresponding to the rotating pin diameter is seen as the green region in the hardness map of $360 \mathrm{HV}$. This region corresponds to the volume of the rotating pin diameter and is also an important indication of material flow during FSP. This region has a lath martensitic microstructure with a homogeneous distribution. The stir zone of 1st pass process is affected by the heat generated by the next pass process, and the hardness drop in this zone is clearly observed with a light blue color. A similar characteristic feature is observed in the second pass process and each process is affected by the heat of the next pass process, and the hardness at the end decreases down to 250-300 HV. The microstructure of this transition region is a predominantly bainitic structure consisting of cementite and ferrite. The $\mathrm{HAZ}$ microstructure of retreating side is tempered martensite and this microstructure has $200 \mathrm{HV}$ hardness in a very narrow region of about $250 \mu \mathrm{m}$. Since the hardness profile represents the dark blue 200-250 HV micro hardness range in the color mapping, the hardness decrease in the tempered martensite is not clearly visible.
The tensile test results of DP 600 steel before and after M-FSP are summarized in Table 1. DP 600 steel base plate sample displayed a high elongation with a large strain hardening region which is a typical characteristic of dual phase steels. The yield strength and ultimate tensile strength of base plate were $412 \mathrm{MPa}$ and $615 \mathrm{MPa}$, respectively. On the other hand, the SZs of 1st pass, 2nd pass and 3rd pass processed samples exhibited yield strength values of $321 \mathrm{MPa}, 349 \mathrm{MPa}$ and $657 \mathrm{MPa}$, respectively, and the ultimate tensile strength values of $560 \mathrm{MPa}$, $555 \mathrm{MPa}$ and $830 \mathrm{MPa}$, respectively. The low strength values exhibited by the SZs of 1st pass and 2nd pass FSPed samples compared to that of the base plate may be attributed to the fact that the microstructures of these samples transformed from initial martensiteferrite structure to a predominantly bainitic structure. As seen from Table 1, no significant decrease in elongation was observed after M-FSP and all the specimens exhibited similar elongation values to that of the base plate.

Tab le 1. Main Strength and Ductility Values of each stir zone after M-FSP

\begin{tabular}{|l|c|c|c|}
\hline \multicolumn{1}{|c|}{ Samples } & $\begin{array}{c}\text { Yield Strength } \\
(\mathrm{MPa})\end{array}$ & $\begin{array}{c}\text { Ultimate Tensile } \\
\text { Strength } \\
(\mathrm{MPa})\end{array}$ & $\begin{array}{c}\text { Elon- } \\
\text { gation } \\
(\%)\end{array}$ \\
\hline DP 600 & 412 & 655 & 28 \\
\hline SZ of 1.Pass & 321 & 560 & 30 \\
\hline SZ of 2.Pass & 349 & 555 & 31 \\
\hline SZ of 3.Pass & 657 & 830 & 25 \\
\hline
\end{tabular}

\section{Conclusions}

Multi-pass friction stir process (M-FSP) technique was applied to DP 600 steel and their microstructural and mechanical properties of the M-FSPed plates have been investigated. The results of this study can be summarized as follows:

- The microstructure of the M-FSPed DP600 steel consists of lath martensite, bainite and recrystallized ferrite.

- It was observed that the next pass friction stir process affects the stir zone of the previous pass friction stir processed specimen. The heat generated by the next pass FSP leads to the transformation of lath martensite (formed after the previous pass FSP) 
to cementite and ferrite, thus results in a reduction in hardness.

- The hardness in the processed region increased to an average of $360 \mathrm{HV}$ from $210 \mathrm{HV}$ (hardness of base plate).

- The tensile strength values in the SZ of the first pass process and the second pass process were observed to be 560 and $555 \mathrm{MPa}$, respectively, both of which were lower than that of base plate (i.e., $655 \mathrm{MPa}$ ). This may be attributed to the tempering effect experienced in this regions. On the other hand, the tensile strength of the third process stir zone increased to $830 \mathrm{MPa}$ which is due to the existence of martensitic structure in this sample.

\section{References}

1. Rashid MS. Dual Phase Steels. Ann Rev Mater Sci 1981; 11: 245-67.

2. Nishimoto A, Hosoya Y, Nakaoka K. A new type of dualphase steel sheet for automobile outer body panels. Trans Iron Steel Inst Japan 1981; 21: 778-82.

3. Fonstein N. 7 - Dual-phase steels*. In: Rana R, Singh SB, editors. Automot. Steels, Woodhead Publishing; 2017, p. 169-216.

4. Abid NH, Abu Al-Rub RK, Palazotto AN. Micromechanical finite element analysis of the effects of martensite morphology on the overall mechanical behavior of dual phase steel. Int J Solids Struct 2017; 104-105: 8-24.

5. Kundu A, Field DP. Influence of plastic deformation heterogeneity on development of geometrically necessary dislocation density in dual phase steel. Mater Sci Eng A 2016; 667: 435-43.

6. Ashrafi H, Shamanian M, Emadi R, Saeidi N. A novel and simple technique for development of dual phase steels with excellent ductility. Mater Sci Eng A 2017; 680: 197-202.

7. Son Y Il, Lee YK, Park KT, Lee CS, Shin DH. Ultrafine grained ferrite-martensite dual phase steels fabricated via equal channel angular pressing: Microstructure and tensile properties. Acta Mater 2005; 53: 3125-34.

8. Park K-T, Lee YK, Shin DH. Fabrication of ultrafine grained ferrite/martensite dual phase steel by severe plastic deformation. ISIJ Int 2005; 45: 750-5.

9. Ma ZY. Friction stir processing technology: A review. Metall Mater Trans A 2008; 39: 642-58.

10. Mishra RS, Mahoney MW. Friction stir welding and processing. ASM Int 2007: 368.

11. Çam $G$, İpekoğlu $G$, Küçükömeroğlu $T$, Aktarer SM. Applicability of friction stir welding to steels, Journal of Achievements in Materials and Manufacturing Engineering (JAMME) 2017; 80 (2): 65-85.

12. Çam G, İpekoğlu G. Recent developments in joining of aluminium alloys, Int. J. Adv. Manuf. Technol. 2017; 91 (58): 1851-66

13. Çam G, Mistıkoğlu S. Recent developments in friction stir welding of Al-alloys, Journal of Materials Engineering and Performance (JMEPEG) 2014; 23 (6): 1936-53.

14. Çam G. Friction stir welded structural materials: Beyond Alalloys', Int. Mater. Rev. 2011; 56 (1): 1-48.

15. Mishra RS, Ma ZY. Friction stir welding and processing. Mater Sci Eng R Reports 2005; 50: 1-78.

16. Padhy GK, Wu CS, Gao S. Friction stir based welding and processing technologies - processes, parameters, microstructures and applications: A review. J Mater Sci Technol 2018; 34: 1-38.

17. Węglowski MS. Friction stir processing - State of the art Arch Civ Mech Eng 2018; 18: 114-29.

18. Chaudhary A, Dev AK, Goel A, Butola R, Ranganath MS The mechanical properties of different alloys in friction stir processing: A review. Mater Today Proc 2018; 5: 5553-62.
19. Sudhakar M, Rao CHS, Saheb KM. Production of surface composites by friction stir processing-A review. Mater Today Proc 2018; 5: 929-35.

20. Moustafa E. Effect of multi-pass friction stir processing on mechanical properties for AA2024/ $\mathrm{Al}_{2} \mathrm{O}_{3}$ nanocomposites. Materials (Basel) 2017; 10: 1053.

21. Chen Y, Ding H, Malopheyev S, Kaibyshev R, Cai Z Hui, Yang $\mathrm{W}$ jing. Influence of multi-pass friction stir processing on microstructure and mechanical properties of 7B04-O Al alloy. Trans Nonferrous Met Soc China (English Ed 2017; 27: 789-96.

22. El-Rayes MM, El-Danaf EA. The influence of multi-pass friction stir processing on the microstructural and mechanical properties of Aluminum Alloy 6082. J Mater Process Technol 2012; 212: 1157-68.

23. Nakata K, Kim YG, Fujii H, Tsumura T, Komazaki T. Improvement of mechanical properties of aluminum die casting alloy by multi-pass friction stir processing. Mater Sci Eng A 2006; 437: 274-80.

24. Ramesh KN, Pradeep S, Pancholi V. Multipass frictionstir processing and its effect on mechanical properties of aluminum alloy 5086. Metall Mater Trans A Phys Metall Mater Sci 2012; 43: 4311-9.

25. Singh SK, Immanuel RJ, Babu S, Panigrahi SK, Janaki Ram GD. Influence of multi-pass friction stir processing on wear behaviour and machinability of an Al-Si hypoeutectic A356 alloy. J Mater Process Technol 2016; 236: 252-62.

26. Luo XC, Zhang DT, Zhang WW, Q C, Chen DL. Tensile properties of AZ61 magnesium alloy produced by multi-pass friction stir processing: Effect of sample orientation. Mater Sci Eng A 2018; 725: 398-405.

27. Xu N, Bao Y. Enhanced mechanical properties of tungsten inert gas welded AZ31 magnesium alloy joint using two-pass friction stir processing with rapid cooling. Mater Sci Eng A 2016; 655: 292-9.

28. Alavi Nia A, Omidvar H, Nourbakhsh SH. Effects of an overlapping multi-pass friction stir process and rapid cooling on the mechanical properties and microstructure of AZ31 magnesium alloy. Mater Des 2014;58:298-304.

29. Fattah-Alhosseini A, Attarzadeh FR, Vakili-Azghandi M. Effect of multi-pass friction stir processing on the electrochemical and corrosion behavior of pure titanium in strongly acidic solutions. Metall Mater Trans A Phys Metall Mater Sci 2017; 48: 403-11.

30. John Baruch L, Raju R, Balasubramanian V, Rao AG, Dinaharan I. Influence of multi-pass friction stir processing on microstructure and mechanical properties of die cast Al7Si-3Cu aluminum alloy. Acta Metall Sin (English Lett 2016; 29: 431-40. doi:10.1007/s40195-016-0405-2).

31. Meenia S, Khan MD F, Babu S, Immanuel RJ, Panigrahi SK, Janaki Ram GD. Particle refinement and fine-grain formation leading to enhanced mechanical behaviour in a hypo-eutectic Al-Si alloy subjected to multi-pass friction stir processing. Mater Charact 2016; 113: 134-43.

32. Esmaily M, Mortazavi N, Osikowicz W, Hindsefelt H, Svensson JE, Halvarsson M, et al. Influence of multi-pass friction stir processing on the corrosion behavior of an AlMg-Si slloy. J Electrochem Soc 2016; 163: C124-30.

33. Padhy GK, $\mathrm{Wu} \mathrm{CS}$, Gao S. Friction stir based welding and processing technologies - processes, parameters, microstructures and applications: A review. J Mater Sci Technol 2018; 34: 1-38.

34. Liu FC, Hovanski Y, Miles MP, Sorensen CD, Nelson TW. A review of friction stir welding of steels: Tool, material flow, microstructure, and properties. J Mater Sci Technol 2018; 34: 39-57.

35. Miles MP, Pew J, Nelson TW, Li M. Comparison of formability of friction stir welded and laser welded dual phase 590 steel sheets. Sci Technol Weld Join 2006; 11: 3848.

36. Kang HC, Park BJ, Jang JH, Jang KS, Lee KJ. Determination of the continuous cooling transformation diagram of a high strength low alloyed steel. Met Mater Int 2016; 22: 949-55. 


\title{
ВПЛИВ БАГАТОПРОХІДНОЇ ОБРОБКИ ТЕРТЯМ 3 ПЕРЕМІШУВАННЯМ НА МІКРОСТРУКТУРУ ТА МЕХАНІЧНІ ВЛАСТИВОСТІ ДВОФАЗНОЇ СТАЛІ
}

\author{
Т. КУЖУКОМЕРОГЛИ 1 , С. М. АКТАРЕР², Ж. ІПЕКОГЛИ ${ }^{3}$, Ж. КАМ ${ }^{3}$ \\ ${ }^{1}$ Відділення машинобудування, Технічний університет Караденіз, Трабзон, Туреччина. \\ E-mail: tkomer@ktu.edu.tr \\ ${ }^{2}$ Відділення автомобільної техніки, Університет Реджепа Тайіпа Ердогана, Різе, Туреччина. \\ E-mail: semih.aktarer@erdogan.edu.tr \\ ${ }^{3}$ Відділення машинобудування, Технічний університет Іскендерун, 31200 Іскендерун-Хатай, Туреччина. \\ E-mail: guven.ipekoglu@iste.edu.tr; gurel.cam@iste.edu.tr
}

\begin{abstract}
Двофазні (DP) сталі широко використовуються в автомобільній промисловості завдяки гарним технологічним властивостям, таким як висока міцність та формуємість. Проте останнім часом намагалися покращити властивості механічної та формувальної здатності, щоб досягти подальшої економії ваги. Механічні та мікроструктурні властивості сталі DP можуть бути покращені за допомогою методів пластичної деформації (SPD) без зміни їх хімічних композицій. Серед методів SPD, обробка тертям з перемішуванням (FSP) - це новий метод, що використовується для підвищення властивостей пластин та / або типів листів металів. Тому досліджено ефект багатопрохідного FSP (M-FSP) на мікроструктуру та механічні характеристики сталі DP (тобто DP600). M-FSP застосовується для двофазної сталі на крок 4 мм. FSP призвело до подрібнення мікроструктури, та значному збільшенню як твердості, так і міцності. Після FSP ділянки мартенситу як вторинної фази в мікроструктурі були порушені обертальним штифтом. Оброблена ділянка складається 3 фериту, бейніту та мартенситу. Значення твердості збільшилося з $210 H V_{0.2}$ до приблизно $360 H V_{0.2}$ після M-FSP. Бібліогр. 36, табл. 1, рис. 4.
\end{abstract}

Ключов і слова: обробка тертям, двофазна сталь, тонкозерниста мікроструктура, механічні властивості

\section{ВЛИЯНИЕ МНОГОПРОХОДНОЙ ОБРАБОТКИ ТРЕНИЕМ С ПЕРЕМЕШИВАНИЕМ НА МИКРОСТРУКТУРУ И МЕХАНИЧЕСКИЕ СВОЙСТВА ДВУХФАЗНОЙ СТАЛИ}

\section{Т. КУЖУКОМЕРОГЛЫ ${ }^{1}$, С. М. АКТАРЕР ${ }^{2}$, Ж. ИПЕКОГЛЫ ${ }^{3}$, Ж. КАМ ${ }^{3}$}

${ }^{1}$ Отделение машиностроения, Технический университет Карадениз, Трабзон, Турция. E-mail: tkomer@ktu.edu.tr ${ }^{2}$ Отделение автомобильной техники, Университет Реджепа Тайипа Эрдогана, Ризе, Турция.

E-mail: semih.aktarer@erdogan.edu.tr

${ }^{3}$ Отделение машиностроения, Технический университет Искендерун, 31200 Искендерун-Хатай, Турция.

E-mail: guven.ipekoglu@iste.edu.tr; gurel.cam@iste.edu.tr

Стали с двухфазной структурой (DP) широко используются в автомобильной промышленности благодаря отличным технологическим свойствам, таким как высокая прочность и хорошая формуемость. Однако в последнее время предпринимаются попытки улучшить их механические свойства и способность к формообразованию, чтобы добиться дополнительной экономии веса. Механические и микроструктурные свойства стали DP могут быть улучшены методами пластической деформации (SPD) без изменения их химического состава. Среди методов обработки метод фрикционного деформирования (FSP) является новым методом, используемым для улучшения свойств листовых или других видов сортамента металлов. В работе изучено влияние многопроходного FSP (M-FSP) на микроструктуру и механические характеристики стали DP (DP600). Влияние M-FSP изучено применительно к двухфазной стали с шагом 4 мм. FSP привела к измельчению микроструктуры и к значительному увеличению как твердости, так и значений прочности. После FSP участки мартенсита как вторичной фазы в микроструктуре были разрушены вращательным штифтом. Обработанная область состоит из феррита, бейнита и мартенсита. Значение твердости увеличилось с $210 H V_{0,2}$ до приблизительно $360 H V_{0,2}$ после M-FSP. Библиогр. 36, табл. 1, рис. 4.

Кл ючев в е слов а: обработка трением, двухфазная сталь, мелкозернистая микроструктура, механические свойства

Поступила в редакцию 16.07.2018

\section{5 лет цельносварному мосту им. Е. О. Патона через Днепр}

4 ноября 1953 г. открыто движение по цельносварному мосту в Киеве длиной 1543 м. Не ожидая полного окончания постройки опытных сварных мостов, было решено приступить к изготовлению и монтажу пролетных строений крупнейшего цельносварного моста через Днепр. Ведущая роль в проектировании, изготовлении и монтаже пролетных строений принадлежала Институту электросварки и лично Е. О. Патону. Проект моста разработан институтом «Укрпроектстальконструкция». Мост имеет 24 пролета, из них четыре судоходных с высотой 87 м. Основной объем работ по сварке главных балок был выполнен разработанными в ИЭС автоматами и полуавтоматами, которыми было сварено 97 \% всех швов.

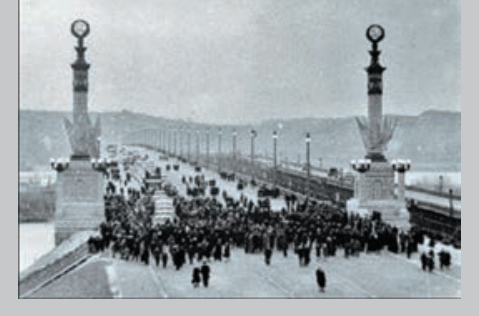

